on the safe side and could be reduced to-day, and the further reductions indicated in this paper will bring the question to a practical proposition. The complete electrification was estimated to require a consumption of 5,400 million units, but probably a good many branch lines would not be electrified, and a total of 4,000 million may suffice. It is not a great addition to the total load, which was close on 16,000 millions last year, but it is a desirable increase, as it will have a good load factor and can be easily provided, for railways and population go together.

There are signs that a low price will bring in large consumers in the metallurgical industries. The use of electric furnaces is rapidly increasing, and below $0.5 d$. the private plant has little chance of competing, if complete reliability is to be ensured. The possible magnitude of this load it would be futile to estimate, but it will be considerable and will have an excellent load factor.

From the foregoing, it is evident that the electric supply industry can be put on the road to a substantial and even to a great increase, and that the new business will materially improve the load factor and reduce costs of distribution. The use of cheap fuel, and an alleviation of the burden of rates, will give the initial stimulus that is needed, and the great increase will automatically recoup the apparent loss to the rate fund of the local authorities.

To sum up the main theme, the Grid and the branch lines should operate not only as distributors of power to the consumer, wherever he may live, but also as collectors of power wherever it may be obtained, and like all successful middlemen, it should buy in the cheapest market and put the consumer into connexion with the nearest pro- ducer, whether small or large. The small producer, in other goods as well as electricity, may show very low costs of production, but fail to find a steady market. The Grid can offer such a market, and while it has no warehouse or other means of storage, it can harmonise the consumer and producer by varying the output of the large stations, which will work on the principle of keeping up the pressure at distribution centres, and the current will flow naturally to where it is demanded. The stations will gradually be placed where their costs are lowest, and the pit-heads and coal-cleaning floors will be their natural sites for the greater part of Great Britain. The economies thus made possible will attract consumers that are at present in doubt, and a great increase will ensue.

The question of the ownership of these large pithead stations will require consideration. Several solutions are possible, but for all of them it is essential that there shall be co-operation between the producers of coal and the producers of electricity. The one party must be assured of a steady sale of their cheap fuel, that they may be willing to remodel their business to suit the new outlet; the other party must be assured of a steady low price, that they may not be exploited after they have given hostages by large expenditure on the new stations. It seems a suitable case for a central control, as without guarantees neither party would be wise to commit themselves, though the advantages to both seem fairly certain and considerable. A proposal of such wholesale common action would have seemed impracticable ten years ago; but we are becoming used to central boards, and the Coal Board and the Electricity Board are already in being for the purpose.

\title{
Aberdeen Meeting of the British Association
}

$\mathrm{N}^{\mathrm{O}}$ OW that the 1934 meeting of the Association has come and gone, it is possible to give some account of matters which were of general interest to the members. That it has been an unqualified success is the opinion of the chief officials of the Association, other members, and the public generally. The proceedings of the Association commenced with the president's address in the Capitol buildings on Wednesday evening, which upwards of 2,300 attended. The building provided was an ideal setting for a memorable opening address.

The two evening discourses were held in the MacRobert Hall, a building which holds about 800 persons, and on both occasions the Hall was well filled. The speakers were Sir Frank Smith, who delivered the Hardy Memorial Lecture, and Prof. W. L. Bragg, and the audience at the close showed their evident appreciation.
The attendance at sectional meetings was almost without exception good, and, in some cases, more persons wished to hear particular papers than could be accommodated comfortably. On the whole, the programmes provided in the sections appear to have satisfied the demands both of the more strictly scientific members and of the general public. The accommodation provided for the meetings of sections was in every way convenient and satisfactory, as also the arrangements for midday meals and other refreshments in proximity to the sectional meeting-places.

Most sections had a very full programme of excursions, of which every advantage was taken. Particular notice should be taken of the Telford Exhibition housed in proximity to the Engineering Section, which was so well patronised that it was arranged to continue the exhibition until the end of the second week. A practical demonstration on 
a steep gradient adjoining the City of the "B.A." noise-silencer was carried out under ideal conditions and was well attended. The river-gauging demonstration some miles up the River Dee proved of interest to a large number of members. An excursion of unique interest arranged by Section A in conjunction with the Deeside Field Club was the excursion to Inverey, near Braemar, for the unveiling of the monument to Johann von Lamont. The president in his official capacity attended, and the unveiling ceremony was performed by Princess Arthur of Connaught. In all, thirty-six excursions of archæological, biological, engineering and geological interest were arranged before the meeting, and some enthusiastic members have arranged for certain post-meeting excursions.

By kind permission of the owners, a number of works in Aberdeen and district was available for inspection by members of the Association. Each of the excursions to these works was fully booked and, in one case, so popular was the excursion that three additional visits had to be arranged. The different research institutes in the neighbourhood-Craibstone Experimental Farm, Macaulay Soil Research Institute, Rowett Research Institute, and the Fishery Board for Scotland's Marine Laboratory and the Research Station of the Department of Scientific and Industrial Researchwere visited by the members of the sections interested in their respective activities as well as by other members of the Association. The Fishery Board for Scotland also generously placed its vessel, the Explorer, at the disposal of the local committee for demonstrations, and the vessel, which was berthed in Aberdeen Harbour during the week, was visited extensively. Five hundred members, in organised excursions, visited the Aberdeen Fish Market at 8 A.M. on two mornings ; and, in addition, the various Corporation departments, particularly the municipal hospitals, attracted the attention of not a few visiting members.

A very full programme of general excursions had been arranged for the Saturday of the meeting, and the longer excursions proved to be very popular. The longest excursion, namely, the
Highland excursion to Inverness, through the Grampians, up the valley of the Spey and homewards by the coast, was booked to its full capacity, and all who took advantage of it were loud in their praises of the provision that had been made for their entertainment at Clava Cairns, Culloden and at Inverness. The Deeside excursion was also well attended and proved interesting to the members of the Association who had selected that excursion. Excursions of somewhat smaller dimensions went to Elgin, the Mearns and Donside. The different excursion parties were favoured with splendid weather, which added in no little measure to their enjoyment and appreciation.

Very ample arrangements were made for the entertainment of the Association by the City and the University. Particular mention should be made of the reception in the Art Gallery and adjoining buildings on the Thursday evening, the luncheon given by the Public Library to a number of the members on Septernber 6, and the garden party in the grounds of King's College on September 11. These were highly appreciated.

On the Sunday of the meeting, an official service attended by the chief office bearers of the Association was held in the West Church of St. Nicholas, when the Principal of the University preached to a very large congregation.

During the meeting, some of the more striking buildings of Aberdeen were flood-lit. Particular mention should be made of the flood-lighting of King's College by gas, as visiting members and others were agreed that it was the most effective and beautiful of the whole range.

The students of the University contributed to the entertainment of the members by having a performance of "Town and Gown" at His Majesty's Theatre during the second half of the meeting. On the special night set aside for members of the Association, the house was packed and the audience showed every sign of appreciation of a fine cavalcade of the history of the City and University. The wind-up of the Association's social activities was a dance in the Beach Ballroom which took place on September 11, after the theatre, and was attended by upwards of seven hundred people.

\section{Obituary}

Sir Thomas Muir, c.m.g., F.R.s.

CIR THOMAS MUIR, who died at Rondebosch, South Africa, on March 21, 1934, was borm on August 25, 1844, at Stonebyres, Lanarkshire, and educated at Wishaw public school and the University of Glasgow. Muir showed equal ability at classics and mathematics, but was persuaded by Kelvin (who influenced him profoundly) to devote himself to the latter.
After holding a small post at the University of St. Andrews and spending some time in Continental travel, Muir was appointed in 1871 to an assistant lectureship in Glasgow, and in 1874 to be chief mathematical and science master in the Glasgow High School, where for eighteen years he taught with notable success. His powers of organisation attracted the attention of Mr. Cecil Rhodes, then Premier of the Cape Colony, and eventually Muir was elected 